\title{
Contamination in Fractured-Rock Aquifers-Research at the former Naval Air Warfare Center, West Trenton, New Jersey
}

\section{The U.S. Geological Survey and cooperators are studying chlori- nated solvents in a fractured sedi- mentary rock aquifer underlying the former Naval Air Warfare Center (NAWC), West Trenton, New Jersey. Fractured-rock aquifers are common in many parts of the United States and are highly susceptible to con- tamination, particularly at industrial sites. Compared to "unconsolidated" aquifers, there can be much more uncertainty about the direction and rate of contaminant migration and about the processes and factors that control chemical and microbial transformations of contaminants. Research at the NAWC is improv- ing understanding of the transport and fate of chlorinated solvents in fractured-rock aquifers and will compare the effectiveness of dif- ferent strategies for contaminant remediation.}

Complex Fractured-Rock Aquifers and Contamination

Toxic chemicals such as chlorinated solvents pose a serious threat to the Nation's ground-water resources. Many industrial sites in the Eastern United States are located in the Piedmont physiographic region, where fractured rock aquifers are common. Improper disposal methods, leaking tanks and pipes, and chemical spills have contaminated fractured-rock aquifers in and around these sites.

The restoration and protection of ground-water quality at these sites depend on knowledge of the physical, chemical, and microbiological processes that affect the transport and fate of these toxic chemicals. To gain this knowledge, the U.S. Geological Survey (USGS) Toxic Substances Hydrology Program, in cooperation with other Federal, State, and private-sector organizations, is conducting multidisciplinary research on

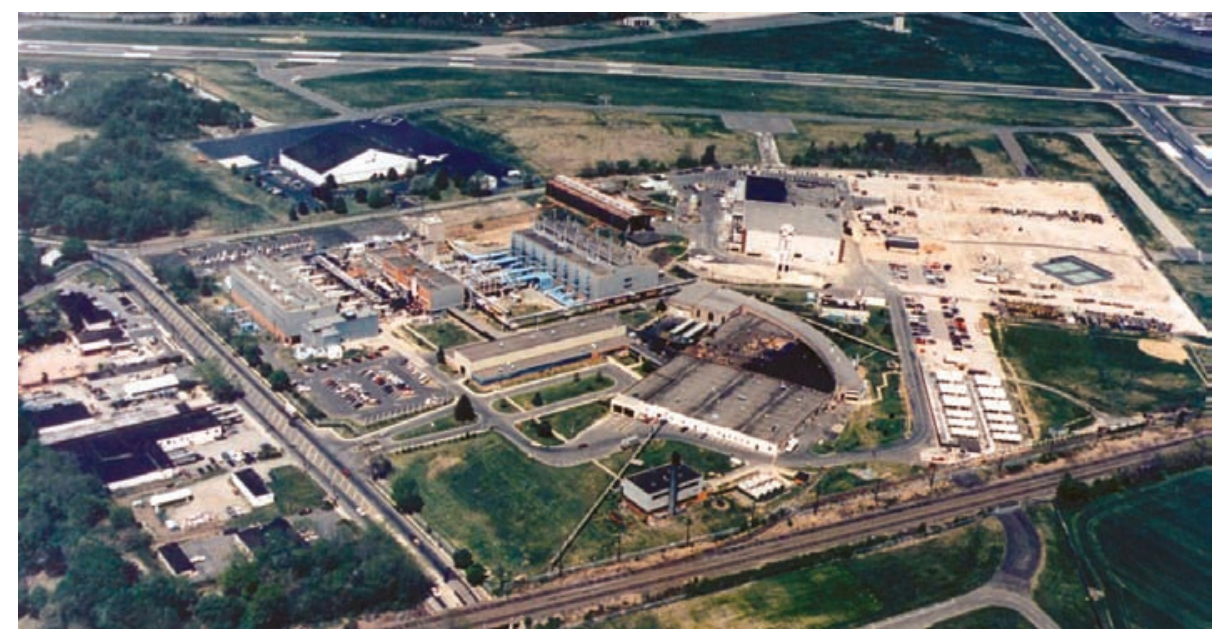

The U.S. Navy tested jet engines at the Naval Air Warfare Center, West Trenton, New Jersey, from the mid-1950s until the late 1990s. Fractured bedrock at the site was contaminated with trichloroethylene (TCE) used during the testing operations.

contamination in fractured sedimentary rock underlying the former Naval Air Warfare Center (NAWC) in West Trenton, New Jersey.

Why Is There Contamination at the NAWC?

The U.S. Navy tested jet engines at the NAWC in West Trenton, New Jersey, from the mid-1950s until the late 1990s. Fractured bedrock at the site was contaminated with trichloroethylene (TCE) used during the engine testing operations. It is likely that heavier-than-water TCE has flowed vertically downward and in the down-dip direction of the fractured sedimentary rocks. An aqueousphase plume of dissolved TCE has flowed along the strike and in the up-dip directions. There is evidence of microbial transformation (biodegradation) of TCE to dichloroethylene (DCE) and vinyl chloride (VC). Investigations of the ground-water contamination at the site began in the late 1980s, and a pump and treat operation that has successfully limited offsite migration was started in the mid-1990s.

\section{Multidisciplinary and Cooperative Research}

One objective of the cooperative research at the NAWC is to improve scientific understanding of physical, chemical, and microbial processes affecting the transport and fate of chlorinated solvents, including the role of dense nonaqueous phase liquid (DNAPL) TCE as a long-term source. The research also will develop methods for cost effective subsurface monitoring and will compare different strategies for cleaning up TCE in fractured-rock aquifers. The NAWC site was chosen for this research because the general hydrogeologic framework is well defined and the site contains extensive contamination over a range of geochemical conditions.

In 1993, the USGS began studies at the NAWC in cooperation with the U.S. Navy.

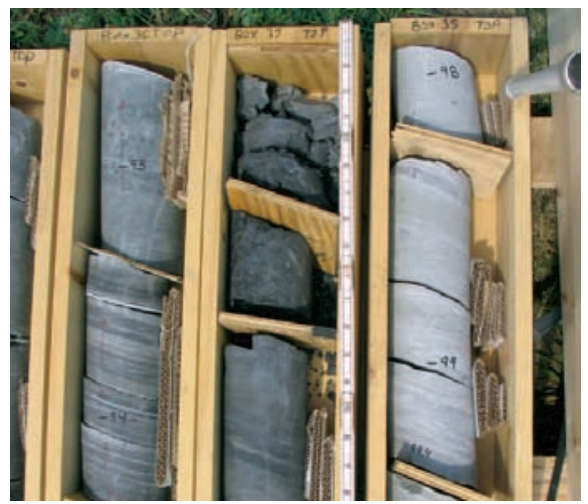

Rock cores from a borehole at the NAWC, showing the dipping mudstone strata that are pathways for ground-water flow and chemical transport. 


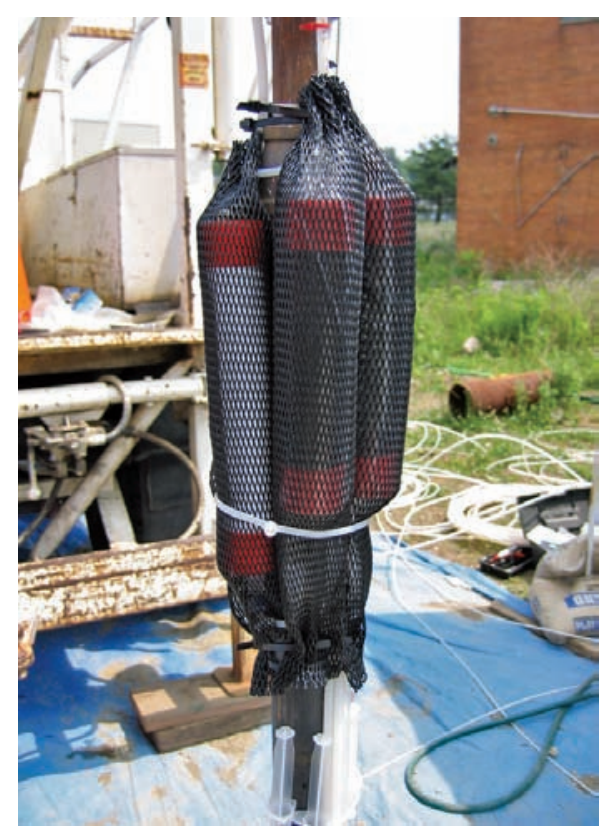

Low-cost diffusion samplers are placed in wells at the NAWC to monitor contaminant concentrations and geochemistry.

In 2001, The USGS began the multidisciplinary, cooperative research effort that currently also involves scientists from the Navy, New Jersey Department of Environmental Protection and New Jersey Geological Survey, and universities and other research institutions. A 2005 biostimulation and bioaugmentation study was conducted with private sector researchers-Geosyntec Consultants and ECOR Solutions - on behalf of the Navy. Research support is provided by the USGS, the Navy, the U.S. Environmental Protection Agency (EPA), and the U.S. Department of Defense Strategic Environmental Research and Development Program (SERDP), operated in partnership with EPA and the U.S. Department of Energy.

\section{Finding Pathways in Fractured Rock}

Understanding contaminant fate in fractured rock and designing effective remediation

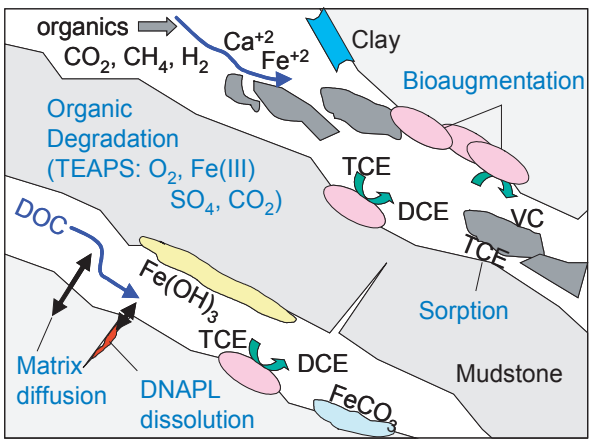

Conceptual diagram of contaminant transport and degradation processes in fractured mudstone. TCE, trichloroethylene; DCE, dichloroethylene; VC, vinyl chloride; DNAPL, dense nonaqueous phase liquid. strategies first requires identifying the paths of fluid and chemical movement. USGS, in cooperation with the U.S. Navy, has characterized in detail the hydrogeologic framework at the NAWC, revealing the three-dimensional distribution of dipping sequences of fissile, laminated, and massive mudstones, primarily by correlation of core and gamma-ray logs. Hydraulically active pathways for ground-water flow and chemical transport are identified using cross-hole flow logging, aquifer tests, and tracer tests. Current research for understanding the hydrogeologic framework and finding flow paths includes surface geophysical surveys, investigations of a fault zone, and numerical ground-water flow modeling.

\section{Monitoring Contaminants, Geochemistry, and Remediation}

In fractured rock, contaminant concentrations and water geochemistry can vary dramatically over short distances, and remediation strategies need to account for this spatial variability. At the NAWC, the spatial and temporal distribution of TCE, DCE, and VC contamination has been characterized using about 100 wells open to short intervals of the bedrock and overlying saprolite (thoroughly weathered clay-rich rock). Concentrations of these contaminants indicate partial biodegradation of TCE to DCE and VC, but rates are low and degradation appears to be stalled in many locations. Ongoing pumping removes contaminated ground water, but the concentration of TCE in many wells remains high, suggesting that some contaminant mass lies in low-permeability fractures and in the primary porosity of unfractured rock.

Planned monitoring research includes characterizing contaminant mass in the rock matrix and investigating rates of TCE and bacteria migration between hydraulically conductive fractures and low-permeability zones using tracer tests and low-cost diffusion sampling methods.

\section{Investigating Biodegradation}

The natural biodegradation of TCE under anaerobic conditions often does not progress beyond DCE and VC. Bioaugmentation is a method of enhancing this process, and involves injecting into the subsurface a viable biological culture and a sufficient amount of electron donor (an energy source for the microorganisms) to support the reductive dechlorination of TCE and its daughter products. Beginning in July 2005, a pilot scale bioaugmentation system was implemented at the NAWC by the U.S. Navy. Substantial reduction of TCE, DCE, and VC has been observed. Current research on biodegradation includes characterization of bacteria and processes that control degradation by using measurements of DNA, hydrogen and other gas concentrations, and carbon isotopes of TCE, DCE, and VC.

\section{Synthesizing Multidisciplinary Data and Predicting Contaminant Fate}

Numerical reactive transport models are powerful tools for synthesizing multidisciplinary data at contaminant sites and for predicting contaminant fate and remediation. Planned reactive transport modeling (RTM) at the NAWC will include the simulation of contaminant transport between the rock matrix and fractures, geochemical reactions, and biodegradation. RTM will build on ground-water flow modeling currently underway to help identify flow and transport paths. RTM will be used to synthesize physical and biogeochemical data; better understand the processes controlling transport and biodegradation of TCE, DCE, and VC; and simulate contaminant mass removal rates by pump and treat, monitored natural attenuation, and enhanced biodegradation. Comparison of the mass removal rates of contaminants by these three methods in fractured rock underlying the NAWC will provide valuable information towards designing costeffective, efficient remediation strategies for many other fractured-rock aquifers across the Nation.

Daniel J. Goode, Claire R. Tiedeman, Pierre J. Lacombe, Thomas E. Imbrigiotta, Allen M. Shapiro, and Francis H. Chapelle

Edited by James W. Hendley II Layout by David R. Jones

\section{COOPERATING ORGANIZATIONS}

U.S. Navy

U.S. Environmental Protection Agency U.S. Department of Defense, Strategic Environmental Research and Development Program

New Jersey Department of Environmental Protection

New Jersey Geological Survey

Michigan State University

Rutgers University

Temple University

University of Kansas

University of South Carolina

Geosyntec Consultants ECOR Solutions

For more information contact:

djgoode or tiedeman@usgs.gov

http://toxics.usgs.gov/sites/nawc_page.html http://nj.usgs.gov/nawc/

This Fact Sheet and any updates to it are available online at http://pubs.usgs.gov/fs/2007/3074/ 